\title{
SEM observations on seeds of some herbaceous Phyllanthus $L$. species (Phyllanthaceae)
}

\author{
Clarice A. Machado ${ }^{1 *}$, Paulo L. de Oliveira ${ }^{2}$, Lilian A. Mentz ${ }^{2}$ \\ ${ }^{1}$ Pontifícia Universidade Católica do Rio Grande do Sul, Faculdade de Farmácia, Laboratório de Farmacognosia, \\ Av. Ipiranga 6681, Prédio 12, 90619-900, Porto Alegre, RS, Brasil, \\ ${ }^{2}$ Programa de Pós-Graduação em Botânica - PPG-BOT, UFRGS, Av. Bento Gonçalves 9500, 91570-950, \\ Porto Alegre, $R S$
}

\begin{abstract}
RESUMO: “Observações de sementes de algumas espécies herbáceas de Phyllanthus L. (Phyllanthaceae) em MEV". Seis espécies herbáceas de Phyllanthus L. (P. tenellus Roxb., P. niruri L., P. stipulatus (Raf.) Webster, P. urinaria L., P. caroliniensis Walt. e P. amarus Schum. \& Thonn.) mencionadas como medicinais apresentam dificuldades na identificação. Com o objetivo de auxiliar neste problema e determinar diferenças entre as espécies, o padrão de ornamentação das sementes foi estudado utilizando técnicas de microscopia eletrônica de varredura (MEV). As sementes apresentaram ornamentação distinta, sendo observadas as superfícies laterais, dorsais e ventrais. As espécies puderam ser separadas em três tipos de ornamentação, que demonstraram importância como caractere diagnóstico para a sua separação.
\end{abstract}

Unitermos: Phyllanthus, Phyllanthaceae, ornamentação da superfície da semente, microscopia eletrônica de varredura (MEV).

\begin{abstract}
Six medicinal herbaceous Phyllanthus L. (Phyllanthaceae) species, P. tenellus Roxb., P. niruri L., P. stipulatus (Raf.) Webster, $P$. urinaria L., $P$. caroliniensis Walt., and $P$. amarus Schum. \& Thonn. are difficult to distinguish. In order to solve this problem, the ornamentation of the seed surfaces was analyzed by SEM (scanning electron microscopy). Differences between lateral, dorsal and ventral surfaces were observed. The seeds were cut into sections at different angles, exposing testa sculptures. Three types of surface ornamentation patterns were observed and they showed to be avaluable diagnostic.
\end{abstract}

Keywords: Phyllanthus, Phyllanthaceae, seed ornamentation, scanning electron microscopy (SEM).

\section{INTRODUCTION}

The genus Phyllanthus L. has a pan-tropical distribution, with over 800 described species of trees, shrubs, and herbs (Webster; Carpenter, 2002). According to Judd et al. (2002), APG II (2003), and Samuel et al. (2005) Phyllanthus genus should be now reported as belonging to the Phyllanthaceae family, instead to the former subfamily Phyllanthoideae of the Euphorbiaceae. Phyllanthus species are largely used in Brazilian traditional or folk medicine as a diuretic and are also indicated in the treatment of jaundice, hepatitis, kidney stones and diabetes (Oliveira; Saito, 1987/1989; Calixto et al., 1997; Calixto et al., 1998).

This complex genus is considered to have at least ten subgenera (Webster, 1967). It is difficult to identify the species correctly, such as the case of $P$. niruri and P. amarus (Unander et al., 1990; 1991; 1992), and to establish which of the species has useful medicinal properties with the available ethno-botanical and ethnopharmacological data. In herbaceous Phyllanthus, floral characters have limited utility for the identification of species and supra-specific taxa, due to the small size of the flowers and the relative narrow range of variation in number and shape of parts, but it is unquestionable that the mean size and the ornamentation pattern of seeds tend to be the best diagnostic (Webster, 1970; Silva; Sales, 2004). Based on a literature revision, the present work focuses on some medicinal herbaceous Phyllanthus species occurring in Brazil known as "quebra-pedra" (Smith; Downs, 1959; Smith et al., 1988; Falcão et al., 2005; Barbosa-Filho et al., 2005) in order to study the surface ornamentation patterns of P. amarus Schum. \& Thonn., P. caroliniensis Walt., P. niruri L., P. stipulatus (Raf.) Webster, P. tenellus Roxb., and P. urinaria L. seeds. The infra-generic classification of the six Phyllanthus 
Table 1. Infrageneric classification of six herbaceous Phyllanthus species, according to Webster $(1967 ; 1970 ; 2002)$ focused on seed SEM analyses.

\begin{tabular}{|c|c|c|c|}
\hline Subgenera & Section & Subsection & Species \\
\hline Isocladus Webster & $\begin{array}{l}\text { Loxopodium Webster } \\
(1967 ; 1970)\end{array}$ & & P. caroliniensis Walt. \\
\hline Kirganelia (Juss.) Webster & $\begin{array}{l}\text { Pentandra Webster (1967; } \\
\text { 1970) }\end{array}$ & & P. tenellus Roxb. \\
\hline \multirow[t]{4}{*}{ Phyllanthus } & $\begin{array}{l}\text { Phyllanthus (1967; 1970; } \\
\text { 2002) }\end{array}$ & $\begin{array}{l}\text { Niruri Webster (1967; } \\
\text { 1970; 2002) }\end{array}$ & P. niruri $\mathrm{L}$. \\
\hline & & $\begin{array}{l}\text { Swartziani Webster } \\
(1967 ; 1970 ; 2002)\end{array}$ & P. amarus Schum. \& Thonn. \\
\hline & & $(1967 ; 2002)$ & P. stipulatus (Raf.) Webster \\
\hline & $\begin{array}{l}\text { Urinaria Webster (1967; } \\
\text { 1970) }\end{array}$ & & P. urinaria $\mathrm{L}$. \\
\hline
\end{tabular}

species listed below (Table 1) is based on Webster (1967; 1970; 2002).

Chen and Wu (1997) compared SEM photographs of pollen grains and seed surface ornamentation of herbaceous Phyllanthus species in Taiwan. They studied P. amarus Schum. \& Thonn., P. tenellus Roxb., P. urinaria L. subsp. nudicarpus Rossign. $\&$ Haic., reviewed in this paper, and other five species. Also Silva and Sales (2004) studied some species with a taxonomic approach, with short seed descriptions and illustrations.

\section{MATERIAL AND METHODS}

Seeds of Phyllanthus amarus, P. caroliniensis, $P$. niruri, $P$. tenellus, and $P$. urinaria were kindly provided by the experimental station CPQBA-UNICAMP (courtesy of Prof. Dr. Pedro Melillo de Magalhães, Campinas-SP, Brazil), and were also collected from the field at different locations in Brazil. The seeds of $P$. stipulatus were collected from the field. The vouchers are deposited at ICN herbarium, UFRGS (Brazil) (Table 2). Five mature seeds of each species were air dried and selected for the exposure of ventral, lateral, and dorsal views, and divided into sections to verify ornamentation pattern on longitudinal or transversal view (Chen; $\mathrm{Wu}$, 1997). They were mounted on stubs with double-sided carbon adhesive tape. The specimens were gold coated (20-25 nm), post-coated with carbon on ion sputter coater (Bal-Tec SCD 005), and observed under XL-30 Philips Scanning Electron Microscope at $15 \mathrm{kV}$ accelerating voltage. The terminology used for surface patterns was based on Barthlott (1990) and Barthlott et al. (1998) and adapted when needed. In order to determine the terminology of ornamentation pattern of P. amarus and $P$. stipulatus, some sculptures on transversal sections mounted on stubs were broken. The SEM images showed a massive core. According Barthlott et al. (1998), the best word for this structure is "rodlet".

\section{RESULTS AND DISCUSSION}

The six studied species of Brazilian herbaceous Phyllanthus, all seeds were wedge-shaped (trigonous) (Burger; Huft, 1995), and two seeds were present in each locus of the capsular fruits. Through micromorphologic examination of each seed coat, three types of rib disposition on dorsal and ventral face were recognized. The seed descriptions and illustrations of Silva and Sales (2004) for P. amarus, P. caroliniensis, P. niruri, $P$. stipulatus and $P$ tenellus can not be compared with the SEM micromorphology described in Table 2 because of the lower magnification used.

The seed coat on dorsal face of the first type group presented longitudinal ribs with transversal finger-shaped rodlets. In P. amarus (Table 2; Figs 1-6), the seed coat had 6-9 dorsal regular longitudinal ribs, where the rodlet end forms the ribs. The same pattern was recognized in P. stipulatus (Table 2, Figs 7-13), but the finger-shaped rodlets were irregularly arranged in different sizes, forming 11-15 irregular dorsal longitudinal ribs, with spaces between the fingers-shaped rodlets. The lateral and ventral faces results are on Table 2, and the dates (with Figs. 1-6) showed that the seed ornamentation is consistent with Chen and $\mathrm{Wu}$ (1997) studies to $P$. amarus.

In the second type group, the seed coat on 
Table 2. Micromorphology of seeds of some herbaceous Phyllanthus species.

\begin{tabular}{|c|c|c|c|}
\hline \multirow{2}{*}{$\begin{array}{c}\text { Taxa } \\
\text { Phyllanthus L. }\end{array}$} & \multicolumn{3}{|c|}{ Seed ornamentation } \\
\hline & dorsal & lateral & Ventral \\
\hline $\begin{array}{c}\text { P. amarus Schum. \& Thonn. } \\
\text { (ICN 123978; ICN 123979; ICN } \\
\text { 123980; ICN 123981)* }\end{array}$ & $\begin{array}{l}\text { Regular longitudinal ribs } \\
\text { regular finger-shape } \\
\text { transversal rodlets }\end{array}$ & $\begin{array}{l}\text { Regular or irregular } \\
\text { concentric C-shape ribs, regular } \\
\text { longitudinal finger-shape rodlets }\end{array}$ & $\begin{array}{l}\text { Regular or irregular } \\
\text { concentric C-shape ribs, regular } \\
\text { longitudinal finger-shape rodlets }\end{array}$ \\
\hline $\begin{array}{c}\text { P. caroliniensis Walt. (ICN } \\
\text { 123971; ICN 123972; ICN } \\
123973) *\end{array}$ & $\begin{array}{l}\text { Stellate verrucose aligned on a } \\
\text { regular longitudinal ribs, } \\
\text { with crusts }\end{array}$ & $\begin{array}{l}\text { Stellate verrucose } \\
\text { regular or irregular concentric C- } \\
\text { shape alignment, with crusts }\end{array}$ & $\begin{array}{l}\text { Stellate verrucose aligned on a } \\
\text { regular or irregular concentric C- } \\
\text { shape ribs, with crusts }\end{array}$ \\
\hline $\begin{array}{l}\text { P. niruri L. (ICN 123950; ICN } \\
\text { 123951; ICN 123952; } \\
\text { ICN123953; ICN 123955) * }\end{array}$ & $\begin{array}{l}\text { Stellate verrucose aligned on a } \\
\text { regular or irregular } \\
\text { longitudinal ribs, with crusts }\end{array}$ & $\begin{array}{l}\text { Stellate verrucose } \\
\text { regular concentric C-shape } \\
\text { alignment, with crusts }\end{array}$ & $\begin{array}{l}\text { Stellate verrucose aligned on a } \\
\text { regular concentric C-shape ribs, } \\
\text { with crusts }\end{array}$ \\
\hline $\begin{array}{c}\text { P. stipulatus (Raf.) Webster } \\
\text { (ICN 123974; ICN 123975; ICN } \\
123976) *\end{array}$ & $\begin{array}{l}\text { Regular or irregular } \\
\text { longitudinal ribs, regular } \\
\text { finger-shape, transversal } \\
\text { rodlets with spaces }\end{array}$ & $\begin{array}{l}\text { Regular or irregular concentric C- } \\
\text { shape ribs regular longitudinal } \\
\text { finger-shaped rodlets }\end{array}$ & $\begin{array}{c}\text { Regular or irregular concentric C- } \\
\text { shape ribs, regular longitudinal } \\
\text { finger-shaped rodlets }\end{array}$ \\
\hline $\begin{array}{l}\text { P. tenellus Roxb. (ICN 123964; } \\
\text { ICN 123965; ICN 123966)* }\end{array}$ & $\begin{array}{c}\text { Stellate verrucose aligned on a } \\
\text { irregular or regular } \\
\text { longitudinal ribs, } \\
\text { with crusts }\end{array}$ & $\begin{array}{l}\text { Verrucose } \\
\text { irregular or regular concentric C- } \\
\text { shape alignment, with crusts }\end{array}$ & $\begin{array}{l}\text { Verrucose aligned on a irregular } \\
\text { or regular concentric } \mathrm{C} \text {-shape } \\
\text { ribs, with crusts }\end{array}$ \\
\hline P. urinaria L. (ICN 123970) * & $\begin{array}{l}\text { Transversal ribs, } \\
\text { microverrucose on ribs, } \\
\text { crusts on valleys }\end{array}$ & $\begin{array}{l}\text { Asymmetrical longitudinal ribs, } \\
\text { microverrucose on ribs, } \\
\text { crusts on valleys }\end{array}$ & $\begin{array}{l}\text { Asymmetrical longitudinal ribs, } \\
\text { microverrucose on ribs, } \\
\text { crusts on valleys }\end{array}$ \\
\hline
\end{tabular}

* Herbarium ICN (UFRGS, Porto Alegre, Brazil)

dorsal face presented longitudinal ribs formed by stellate verrucose ornamentation in longitudinal arrangement. In $P$. caroliniensis (Table 2, Figs 14-20), the seed coat presented a regular pattern of about 10 longitudinal ribs, and the verrucose coat was lost. The verrucose coat and the crust were easily detachable on dorsal and lateral faces. P. niruri (Table 2) presented regular longitudinal and concentric ribs on dorsal and lateral faces (Figs 23-26). However, in some seeds, these ribs were occasionally irregular (Figs 21, 22). P. tenellus (Table 2, Figs 27-32) usually had irregular longitudinal and concentric alignment ribs, with less prominent verrucose ornamentation, which look like a fried egg (Figs 29 and 30), particularly on the lateral face.

The third type was represented by $P$. urinaria (Table 2, Figs 33-38). The seed coat showed transversal ribs on the dorsal face, and longitudinal ribs on the lateral face. This is a typical shape, which was already mentioned by Chen and Wu (1997), bearing symmetrical or asymmetrical ornamentation.

Webster (1956) mentioned a curious and unique kind of seed ornamentation in P. urinaria, as well as the presence of deep pits on the sides of transverse ridges on radial walls. Dot-shaped microverrucose ornamentation was found on the ribs, and crust waxes on dorsal and ventral faces (Figs 34-36). They appear as a deep pit due of their black color. Crusts were mainly found in valleys. The transversal section of all seeds shows pits on the seed coat, and in P. stipulatus (Fig 39), it is easy to see several pits inside the cell wall.

A partial relationship between Webster's (1956; 1967; 1970) infra-generic classification and the three types of ornamentation observed can be implied. The first type of seed ornamentation was found in three distinct subgenera (Isocladus, Kirganelia and Phyllanthus). However, in the last subgenus (Phyllanthus), three types of ornamentation for three species studied were observed, showing the importance and the need of studies on more species of the genus.

There is considerable micromorphological diversity among seeds of herbaceous Phyllanthus species. Our observations reinforce the results of previous studies. A new image on seed of the pits in the seed coat, never published before, was taken. These results, as well as those of Chen and Wu (1997), emphasize the importance of SEM in seeds studies, and underscore the need of 
more extensive use of this technique in taxonomic classifications in Phyllanthaceae.

Phyllanthus niruri and P. tenellus were published in the Brazilian Pharmacopoeia (F. Bras., 2004). The data found in this study allows the differentiation of these herbaceous species from others, and can be used as a diagnostic trait in the assessment of the authenticity of plant raw materials.

\section{ACKNOWLEDGEMENTS}
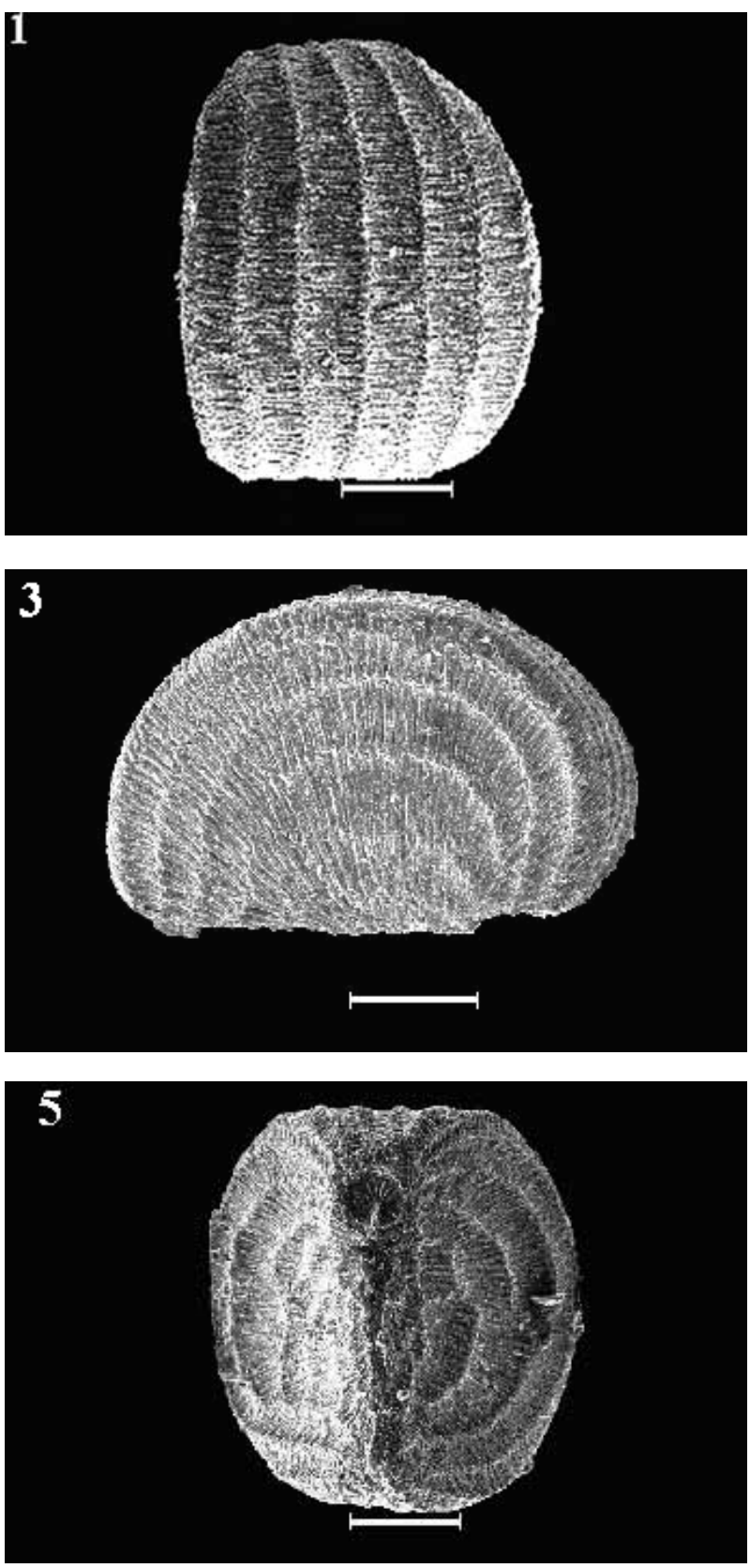

We wish to thank Faculdade de Farmácia PUCRS, Dr. Sérgio de Meda Lamb (in memorian), and CEEM PUCRS (Centro de Microscopia e Microanálises, Pontifícia Universidade Católica do Rio Grande do Sul), Dr. Pedro Melillo de Magalhães from Experimental Station CPQBA-UNICAMP(Campinas, SP-Brasil), Prof. Dr. Nelson Ivo Matzenbacher for collecting some species, Dr. Giovanna Machado and Dr. Carmem Isse Gomes for the images acquisition at XL30 Phillips SEM on CEEM; Dr. Inês Cordeiro (Instituto Botânico de São Paulo-SP) and Dr. Grady L. Webster (UC Davis - Califórnia, in
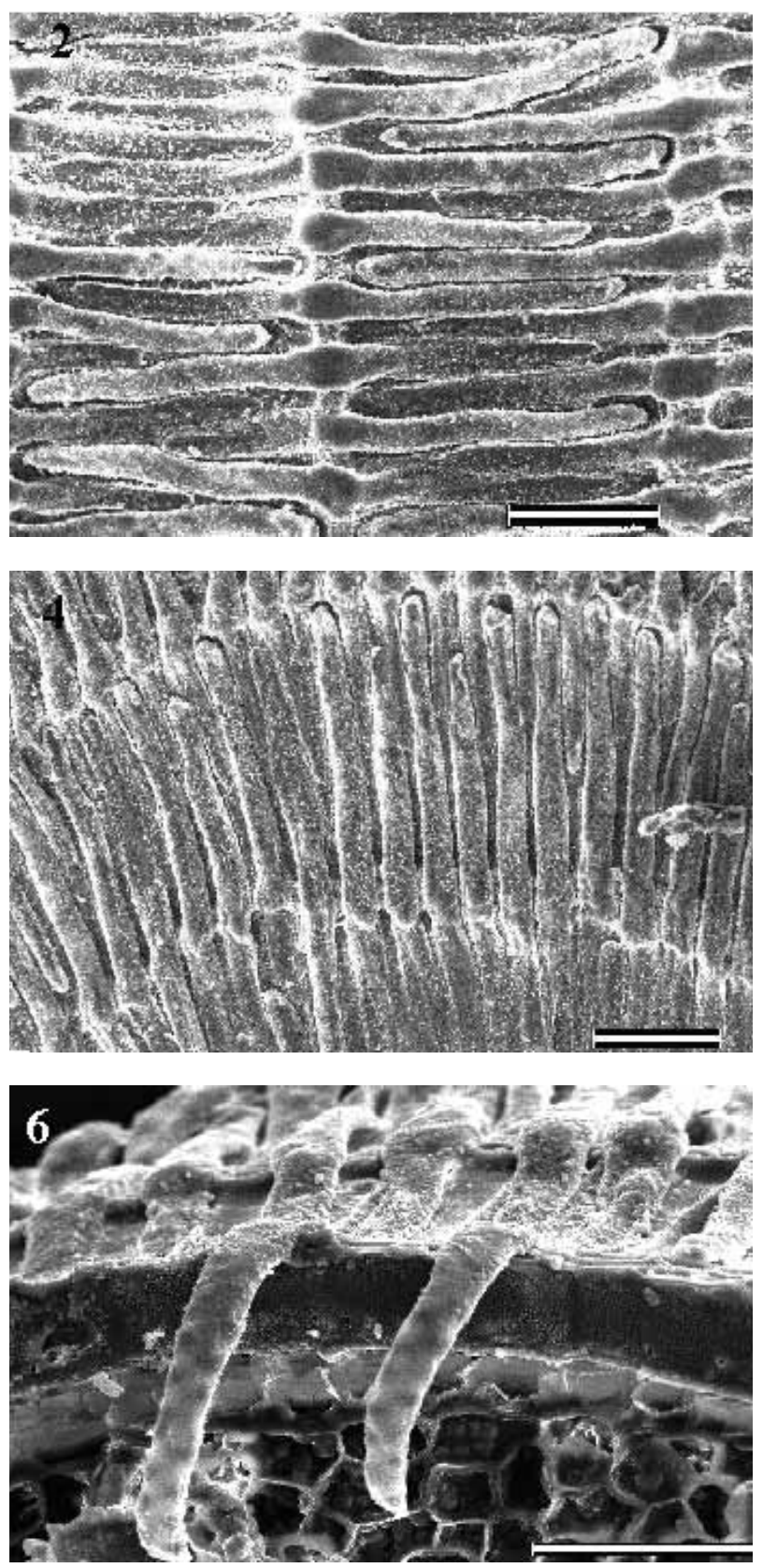

Figures 1-6. Seeds of Phyllanthus amarus. Figs. 1-2 Dorsal view (Scale bar $200 \mu \mathrm{m}$ ). Fig. 2 Detail of the ornamentation showing finger-shape rodlets forming ribs (Scale bar $50 \mu \mathrm{m}$ ). Figs. 3-4 Lateral view (Scale bar $200 \mu \mathrm{m}$ ). Fig. 4 Detail of the ornamentation on lateral face (Scale bar $50 \mu \mathrm{m}$ ). Fig. 5 Ventral view (Scale bar $200 \mu \mathrm{m})$. Fig. 6 Longitudinal section showing epicuticular waxes of rodlets type (Scale bar $50 \mu \mathrm{m}$ ). 

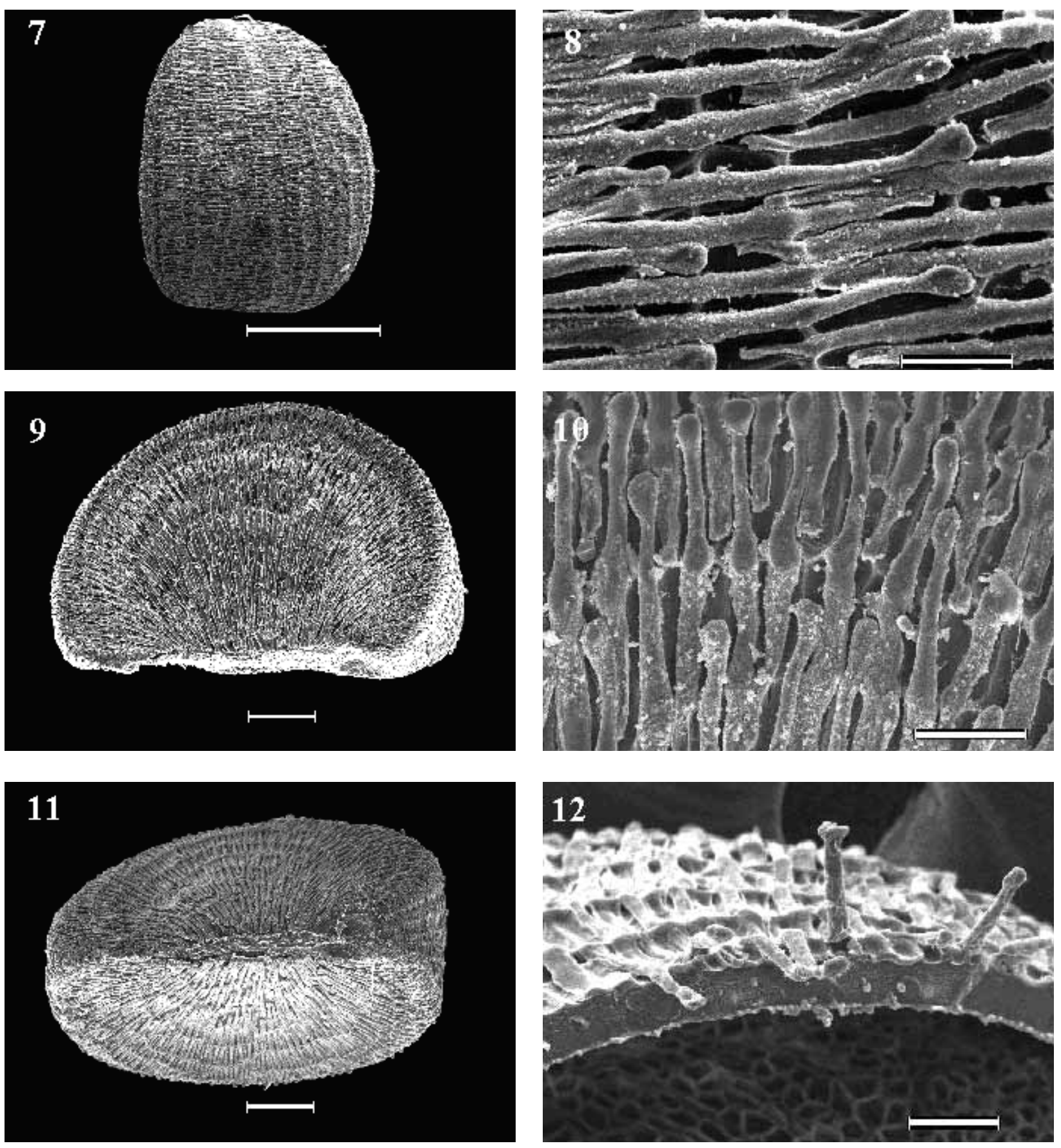

Figures 7-13. Seeds of Phyllanthus stipulatus. Figs. 7-8 Dorsal view (Scale bar $200 \mu \mathrm{m}$ ). Fig. 8 Detail of the irregular ornamentation showing finger-shape rodlets (Scale bar $50 \mu \mathrm{m}$ ). Figs. 9-10 Lateral view (Scale bar $200 \mu \mathrm{m}$ ). Fig. 10 Detail of the ornamentation showing irregular C-shape rib (Scale bar 50 $\mu \mathrm{m})$. Fig. 11 Ventral view (Scale bar $200 \mu \mathrm{m}$ ). Fig. 12 Detail of finger-shape rodlets in longitudinal section of the seed coat (Scale bar $50 \mu \mathrm{m}$ ). Fig. 13 Detail of epicuticular waxes in crosssection of the seed coat (Scale bar $50 \mu \mathrm{m}$ ).

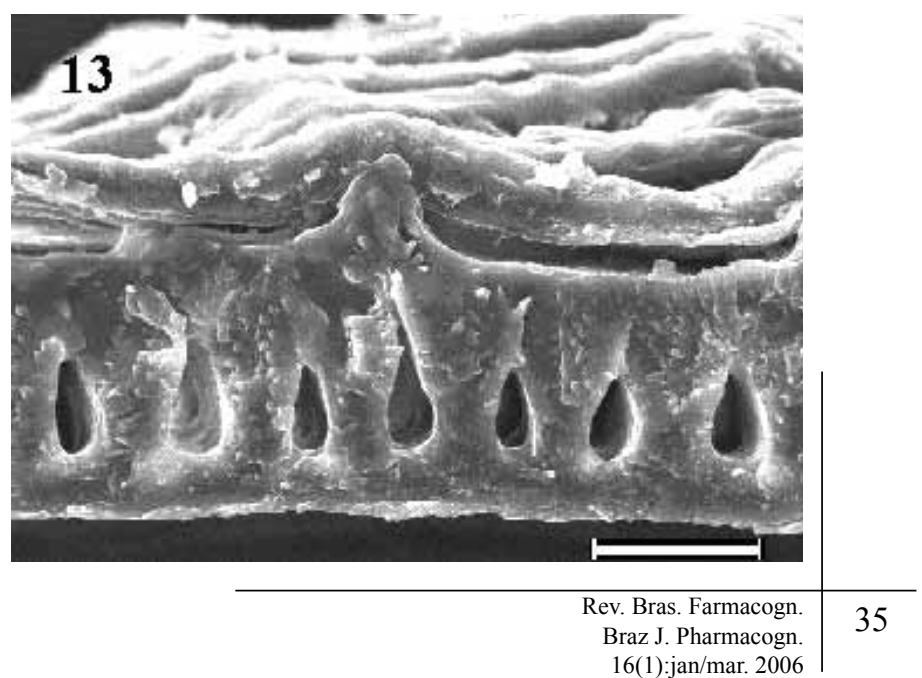



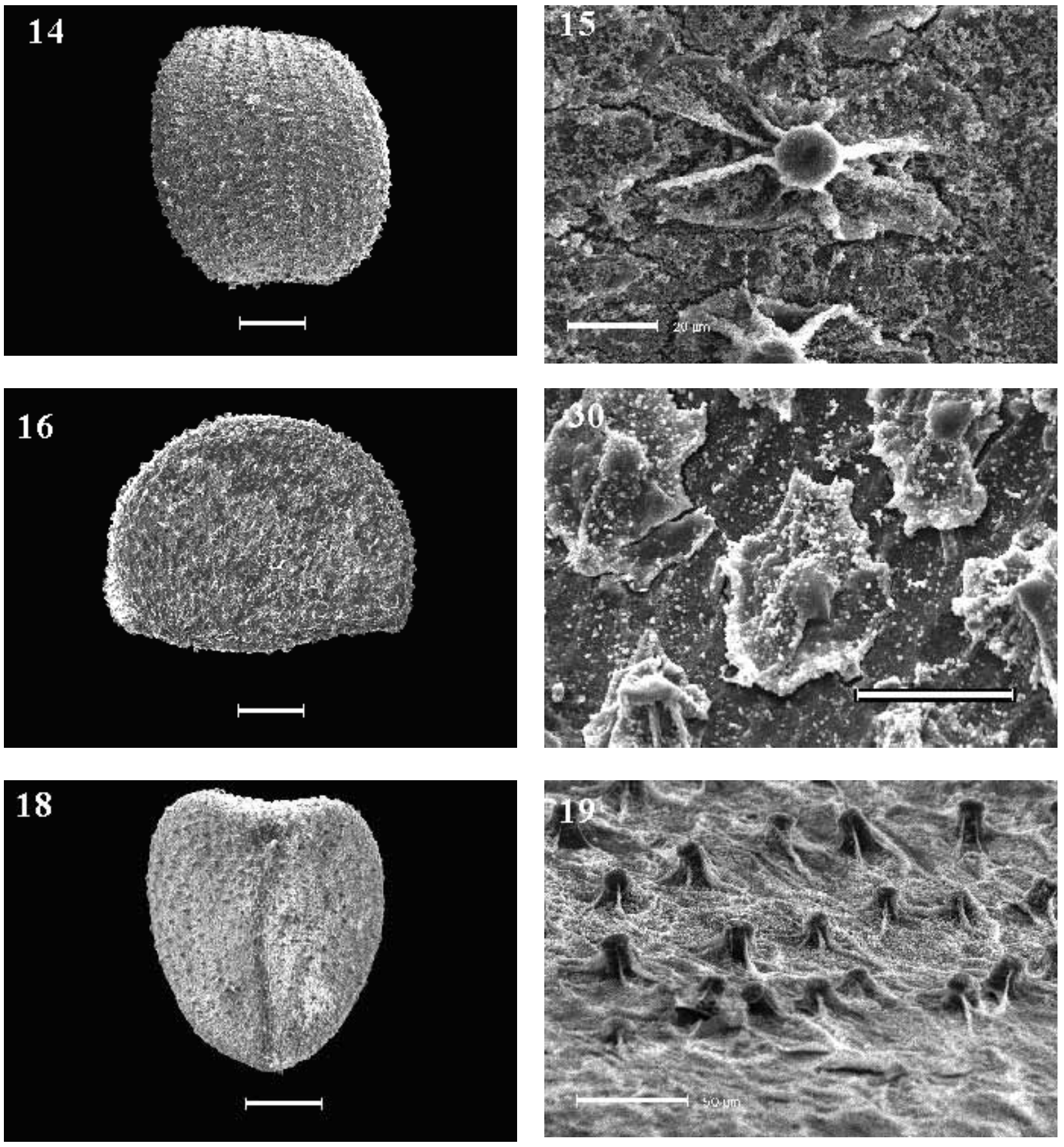

Figures 14-20. Seeds of Phyllanthus caroliniensis. Figs. 14-15 Dorsal view (Scale bar $200 \mu \mathrm{m}$ ). Fig. 15 Detail of the stellate verrucose ornamentation (Scale bar $50 \mu \mathrm{m}$ ). Figs. 1617 Lateral view (Scale bar $200 \mu \mathrm{m}$ ). Fig. 17 Detail of irregular ornamentation showing stellate verrucose forms with crusts (Scale bar $50 \mu \mathrm{m}$ ). Fig. 18 Ventral view. Note regular concentric C-shape alignment of stellate verrucose (Scale bar $200 \mu \mathrm{m}$ ). Fig. 19 Detail of stellate verrucose ornamentation on ventral view (Scale bar $50 \mu \mathrm{m}$ ). Fig. 20 Detail of stellate verrucose ornamentation in cross-section of seed coat (Scale bar $20 \mu \mathrm{m}$ ).

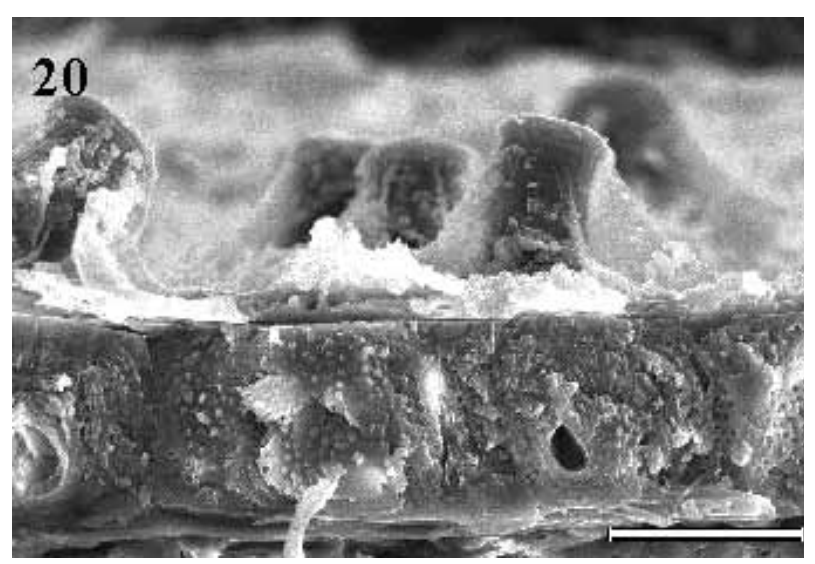



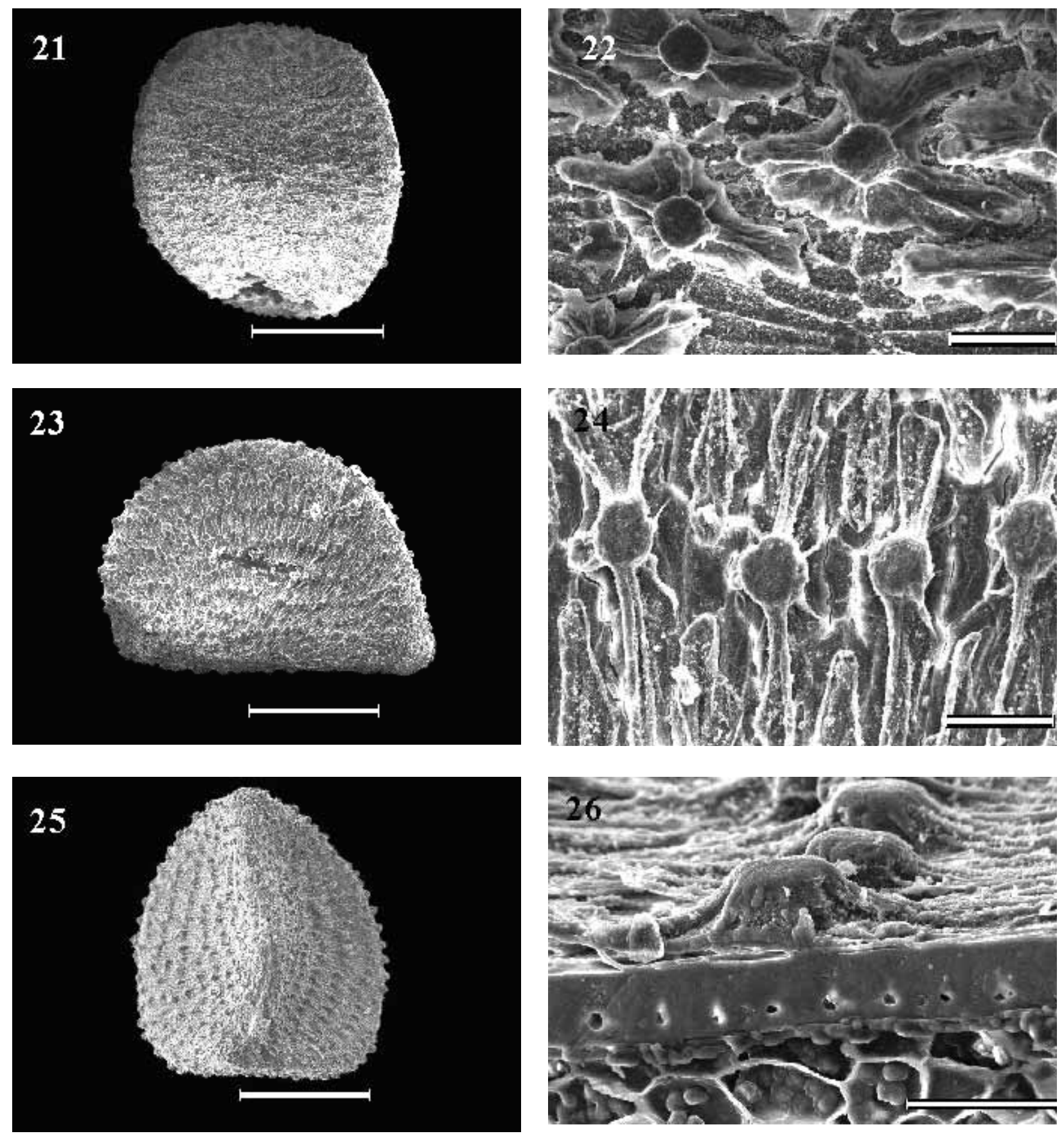

Figures 21-26. Seeds of Phyllanthus niruri. Figs. 21-22 Dorsal view (Scale bar $500 \mu \mathrm{m}$ ). Fig. 22 Detail of the stellate verrucose ornamentation (Scale bar $50 \mu \mathrm{m}$ ). Figs. 23-24 Lateral view (Scale bar $500 \mu \mathrm{m}$ ). Fig. 24 Detail of regular stellate verrucose alignment (Scale bar $50 \mu \mathrm{m}$ ). Fig. 25 Ventral view. Note regular concentric C-shape alignment of stellate verrucose ornamentation (Scale bar $500 \mu \mathrm{m})$. Fig. 26 Detail of stellate verrucose ornamentation in cross-section of seed coat (Scale bar $50 \mu \mathrm{m}$ ). 

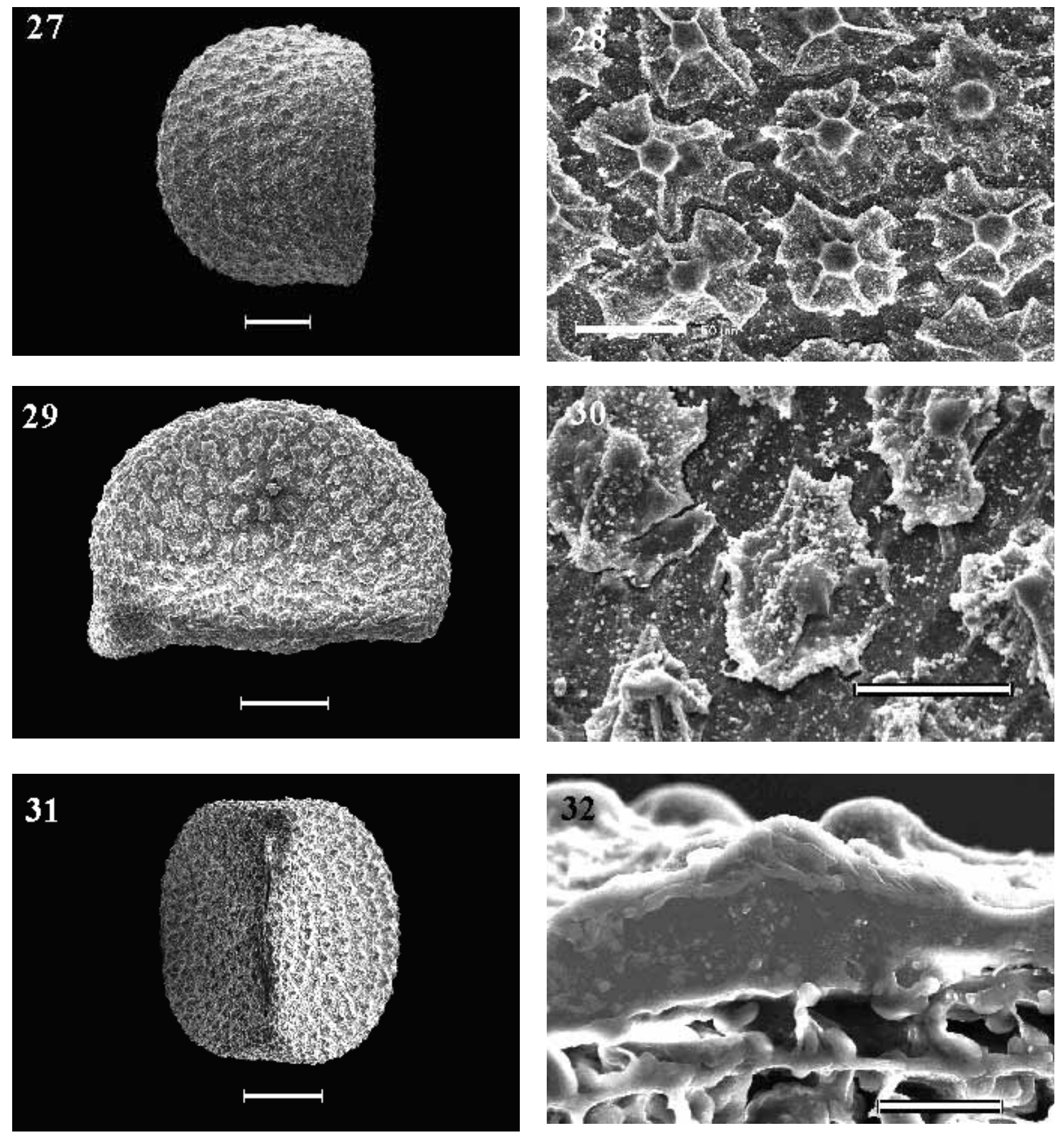

Figures 27-32. Seeds of Phyllanthus tenellus. Figs. 27-28 Dorsal view (Scale bar $200 \mu \mathrm{m}$ ). Fig. 28 Detail of the stellate verrucose ornamentation (Scale bar $50 \mu \mathrm{m}$ ). Figs. 29-30 Lateral view (Scale bar $200 \mu \mathrm{m}$ ). Fig. 30 Detail of verrucose ornamentation on dorsal face (Scale bar $50 \mu \mathrm{m}$ ). Fig. 31 Ventral view. Note regular concentric C-shape alignment of the verrucose ornamentation (Scale bar $200 \mu \mathrm{m})$. Fig. 32 Detail of verrucose ornamentation in cross-section of seed coat (Scale bar $50 \mu \mathrm{m})$. 

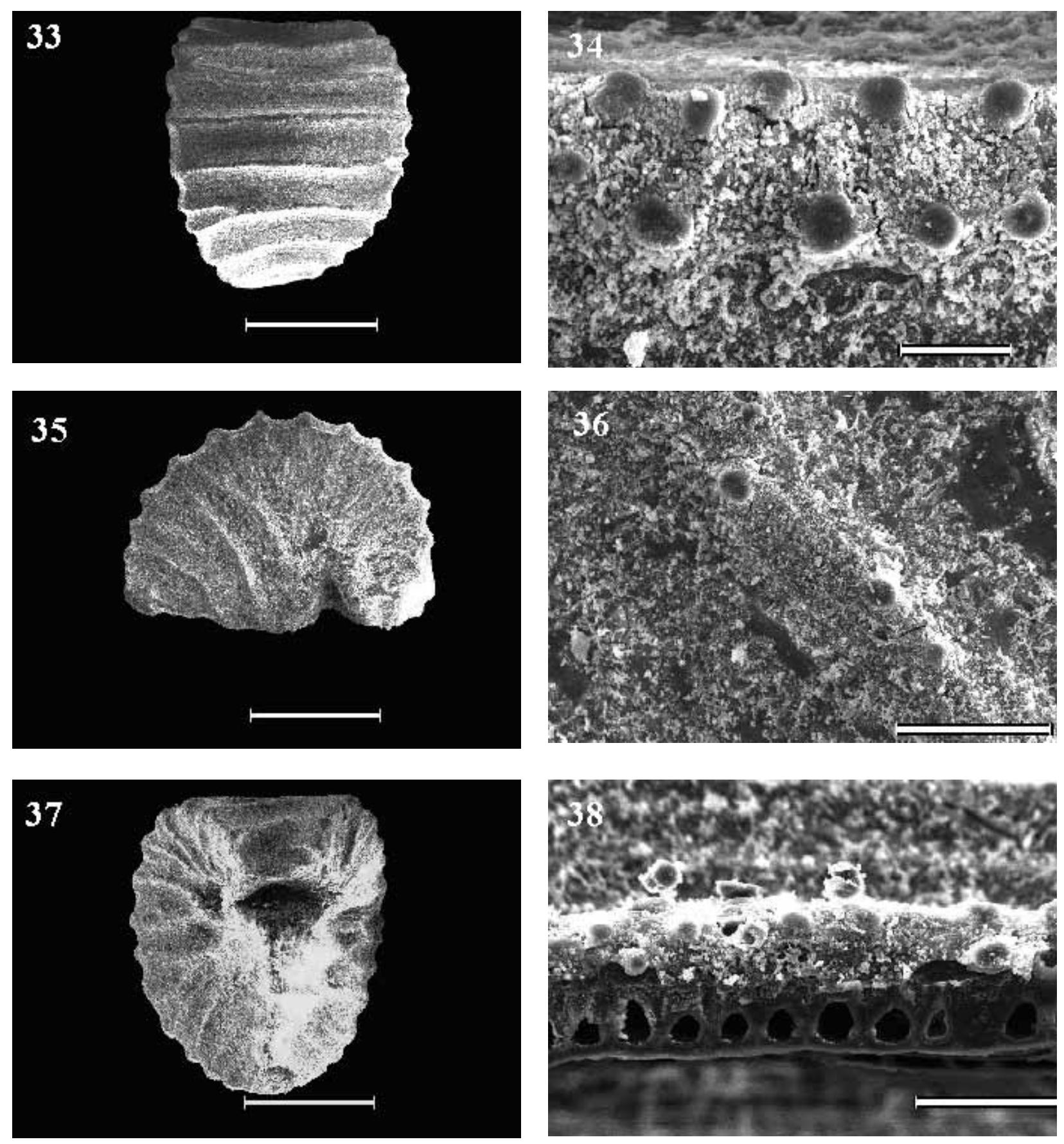

Figures 33-38. Seeds of Phyllanthus urinaria. Figs. 33-34 Dorsal view (Scale bar $500 \mu \mathrm{m}$ ). Fig. 34 Detail of the ribs showing crusts and microverrucose ornamentation (Scale bar $50 \mu \mathrm{m}$ ). Figs. 35-36 Lateral view (Scale bar $500 \mu \mathrm{m}$ ). Fig. 36 Detail of longitudinal rib with crusts and microverrucose ornamentation (Scale bar $50 \mu \mathrm{m}$ ). Fig. 37 Ventral view. Note asymmetrical distribution of the ribs (Scale bar $500 \mu \mathrm{m})$. Fig. 38 Detail of epicuticular waxes in cross-section of seed coat (Scale bar $50 \mu \mathrm{m}$ ). 


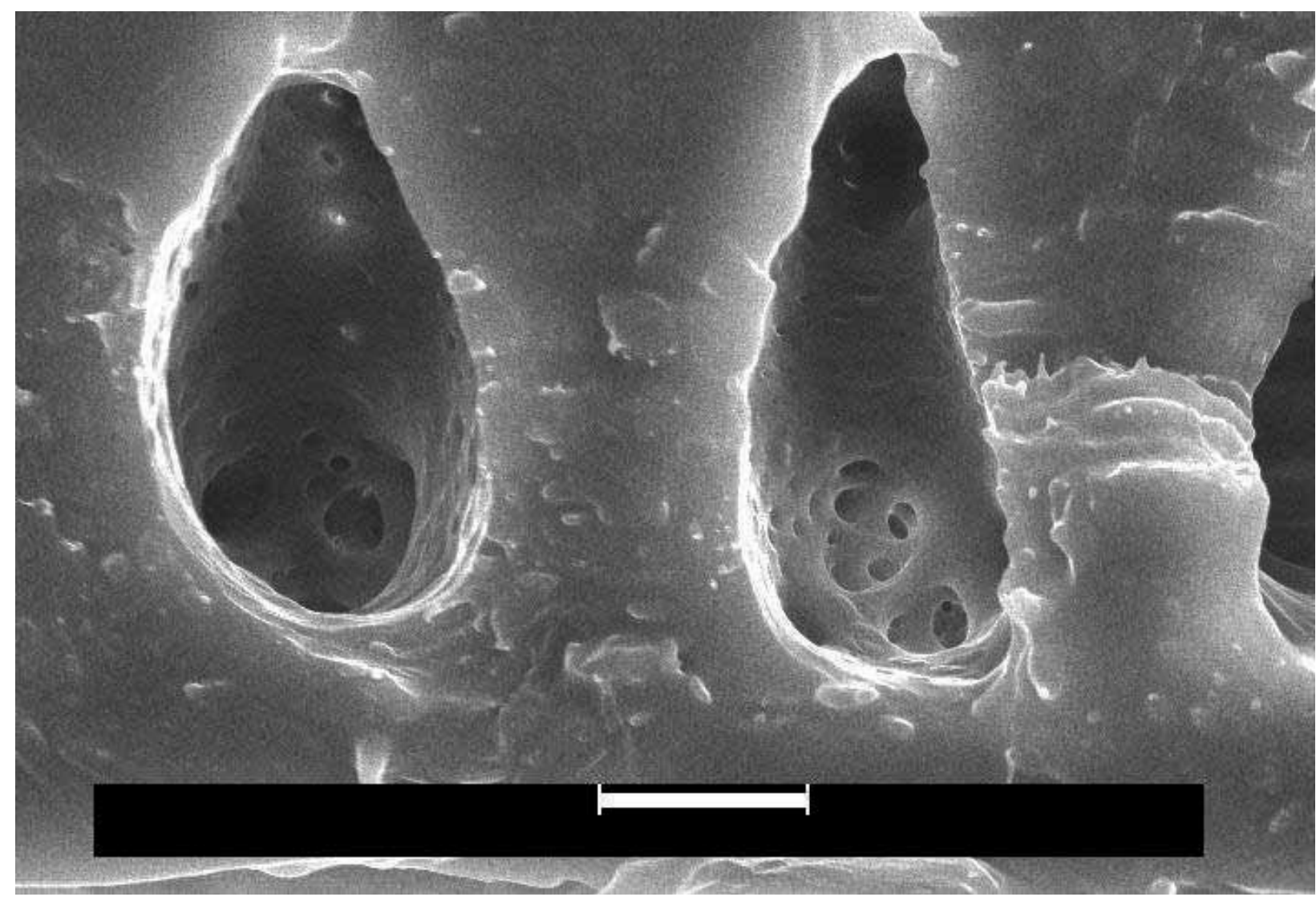

Figure 39. Cross-section of $P$. stipulatus seed. Note pits in the cell wall of the seed coat (Scale bar $5 \mu \mathrm{m})$.

memoriam) for sending some articles and identifications, Dr. Gilsane Lino von Poser from Programa de PósGraduação em Ciências Farmacêuticas (UFRGS), Dr. Eliane Heuser from Faculdade de Biociências (PUCRS) and Dr. Jorge Ernesto de A. Mariath from Programa de Pós-Graduação em Botânica (UFRGS) for their valuable comments and considerations on the manuscript. This work is part of Doctoral Thesis of the first author.

\section{REFERENCES}

APG II (The Angiosperm Phylogeny Group) 2003. An update of the Angiosperm Phylogeny Group classification for the orders and families of flowering plants: APG II. Bot J Lin Soc 141: 399-436.

Barbosa-Filho JM, Vasconcelos THC, Alencar AA, Batista LM, Oliveira RAG, Guedes DN, Falcão HS, Moura MD, Diniz MFFM, Modesto-Filho J 2005. Plants and their active constituents from South, Central, and North América with hypoglycemic activity. Rev Bras Farmacogn 15: 392-413.

Barthlott W 1990. Scanning electron microscopy of the epidermal surface in plants. In: Claugher D. Scanning electron microscopy in taxonomy and functional morphology. Oxford: Clarendon Press, p. 69-94.

Barthlott W, Neinhuis C, Cutler D, Ditsch F, Meussel I, Theisen I, Wilhelm H 1998. Classification and terminology of plant epicuticular waxes. Bot J Lin Soc 126: 237260.

Burger W, Huft M 1995. Flora Costaricensis. Field Botany 36 140-147.

Calixto JB, Santos ARS, Paulino N, Cechinel Filho V, Yunes RA 1997. The plants of the genus Phyllanthus as a potential source of new drugs. Ciên Cult 49: 422432.

Calixto JB, Santos ARS, Cechinel Filho V, Yunes RA 1998. A review of the plants of the genus Phyllanthus: their chemistry, pharmacology, and therapeutic potential. Med Res Rev 18: 225-258.

Chen SH, Wu MJ 1997. A revision of the herbaceous Phyllanthus L. (Euphorbiaceae) in Taiwan. Taiwania 42: 239261.

Judd WS, Campbell CS, Kellog EA, Stevens PF, Donoghue MJ 2002. Plant systematics: a phylogenetic approach. 2 ed. Sunderland: Sinauer. 576 pp.

Falcão HS, Lima IO, Santos VL, Dantas HF, Diniz MMFM, Barbosa-Filho JM, Batista LM. 2005. Review of the plants with anti-inflammatory activity studied in Brazil. Rev Bras Farmacogn 15: 381-391.

Farmacopéia Brasileira 2004. 4. ed. São Paulo: Atheneu, Part II, 5. fascículo, p. 246-247.6.

Oliveira F, Saito ML 1987/1989. Alguns vegetais brasileiros empregados no tratamento de diabetes. Rev Bras Farmacogn 2/4: 170-196.

Samuel R, Kathriarachchi H, Hoffmann P, Barfuss MHJ, Wurdack KJ, Davis CC, Chase MW 2005. Molecular 
phylogenetics of Phyllanthaceae: evidence from plastid matK and nuclear PHYC sequences. Am $J$ Bot 92: 132-141.

Silva MJ, Sales MF 2004. O gênero Phyllanthus L. (Phyllantheae - Euphorbiaceae Juss.) no bioma Caatinga do estado de Pernambuco - Brasil. Rodriguésia 55: 101-126.

Smith LB, Downs RJ 1959. Resumo preliminar das Euforbiáceas de Santa Catarina. Sellowia 11: 155-231.

Smith LB, Downs RJ, Klein RM 1988. Euforbiáceas. Flora Ilustrada Catarinense, Parte I, EUFO, 408 p.

Unander DW, Webster GL, Blumberg BS 1990. Records of usage or assays in Phyllanthus (Euphorbiaceae). I. Subgenera Isocladus, Kirganelia, Cicca and Emblica. J Ethnopharmacol 30: 233-264.

Unander DW, Webster GL, Blumberg BS 1991. Uses and bioassays in Phyllanthus (Euphorbiaceae): a compilation II. The subgenus Phyllanthus. J Ethnopharmacol 34: 97-133.

Unander DW, Webster GL, Blumberg BS 1992. Usage and bioassays in Phyllanthus (Euphorbiaceae): a compilation III. The subgenera Eriococcus, Conami, Gomphisium, Botryanthus, Xylophylla and Phyllanthodendron, and a complete list of the species cited in the three-part series. J Ethnopharmacol 36: 103-112.

Webster GL 1956. A monographic study of the West Indian species of Phyllanthus. J Arn Arbor 37: 217-268.

Webster GL 1967. The genera of Euphorbiaceae in the SouthEastern United States. J Arn Arbor 48: 303-430.

Webster GL 1970. A revision of Phyllanthus (Euphorbiaceae) in the continental United States. Brittonia 22: 44-76.

Webster GL 2002. A synopsis of the Brazilian taxa of Phyllanthus section Phyllanthus (Euphorbiaceae). Lundellia 5: $1-26$.

Webster GL, Carpenter K.J 2002. Pollen morphology and phylogenetic relationships in neotropical Phyllanthus (Euphorbiaceae). Bot J Lin Soc 138: 325-338. 